\title{
The Role of Institutional Policies in Promoting Agribusiness Development in Rural
} China

\author{
Owusu Samuel Mensah ${ }^{1}$ ¿ \\ Zhuang Jincai ${ }^{2}$ \\ Asare Bediako Isaac ${ }^{3}$ \\ Acheampong Patrick ${ }^{4}$ \\ ${ }_{1,2,3,4}$ School of Management, Jiangsu University, Jiangsu, P.R. China \\ 'Email:omensju15@vahoo.com \\ Email:isaacasarib@gmail.com \\ "Email: hidarhwa99@vahoocom
}

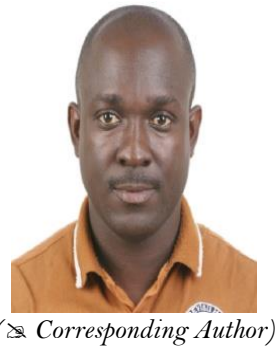

\section{Abstract}

Sustainable agricultural growth has become an area of interest for many researchers in the quest to increase food production in the midst of an escalating population. However, the evidence remains largely scanty, isolated and devoid of an in-depth analysis of how some economic policies promote agribusiness development in mainland China. Using time series data from 1990 to 2013, this paper adopts semi-parametric quantile regression to study the complex relationship between institutional policies in rural areas and agribusiness development. The study revealed the role of family household in promoting agribusiness development at the higher quantiles of the distribution. Moreover, government investment in rural health and education contributed significantly across the quantile distribution. The impact of research and development on agribusiness development is positively significant across the quantile points of the distribution within the study period. The result from the quantile graph clearly shows the disparities between OLS and quantile regression coefficients.

Keywords: Agribusiness development, Institutional policies, Quantile regression, Rural China.

Citation | Owusu Samuel Mensah; Zhuang Jincai; Asare Bediako Isaac; Acheampong Patrick (2017). The Role of Institutional Policies in Promoting Agribusiness Development in Rural China Agriculture and Food Sciences Research, 4(1): 37-44.

\section{History:}

Received: 29 September 2017

Revised: 7 November 2017

Accepted: 13 November 2017

Published: 16 November 2017

Licensed: This work is licensed under a Creative Commons

Attribution 3.0 License (c)

Publisher: Asian Online Journal Publishing Group
Contribution/Acknowledgement: For comments, suggestions and data collection, the authors would like to thank Dr. Emmanuel Opoku Marfo, Li $\mathrm{Na}$, Chen Cong, Li Junqiang and Liu Jiayi.

Funding: National Natural Science Foundation of China (NSFC) supported this research work, with grant number 7147310 .

Competing Interests: The authors declare that they have no conflict of interests.

Transparency: The authors confirm that the manuscript is an honest, accurate, and transparent account of the study was reported; that no vital features of the study have been omitted; and that any discrepancies from the study as planned have been explained.

Ethical: This study follows all ethical practices during writing.

\section{Contents}

1. Introduction

2. Related Literature...u.u... 38

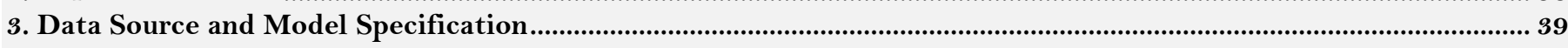

4. Conclusion

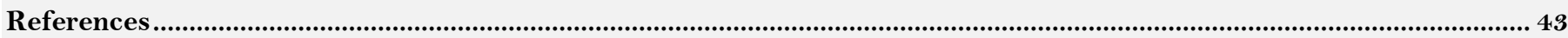




\section{Introduction}

The contribution of agriculture to the growth of the world's economy has been a key policy issue in both Less Economically Developed Countries (LEDC) and More Economically Developed Countries (MEDC). Currently, agriculture, which was previously perceived as a low-tech industry designed for small families and rural dwellers has changed dramatically due to liberalization of the economy and availability of agricultural markets [1, 2]. The contribution of agriculture sector to economic growth and development is manifested through the creation of agricultural and non-agricultural job opportunities and provision of food for both human and animal consumption [3-6]. Currently, China's agricultural sector is facing many challenges due to increasing urbanization and industrialization, which has decreased the productivity growth of agriculture. However, the large growth of human population and the need to increase food production has compelled the Chinese government to introduce agricultural reform policies to remedy the situation $[3,7]$.

Literature has revealed that the rural reforms instituted by China's government have been the backbone of agricultural productivity growth [8-13]. According to Pufahl and Weiss [14] the impact of the central government programs on agricultural production and farm structure is a major issue in the international trade negotiation on agriculture. Moreover, the introduction of the household responsibility system, adjustments of prices of major farm products, tax exemptions given to smallholder farmers, and public investments have contributed enormously to the growth of agricultural sector [12, 15-17]. For instance, with less than $8-10 \%$ of the world's arable, China feeds about $20 \%$ of the world population. In 2008 , the total grain production for the world- wide by China amounted to $18 \%$, it then produced $27 \%$ of its meat and $43 \%$ of its poultry products.

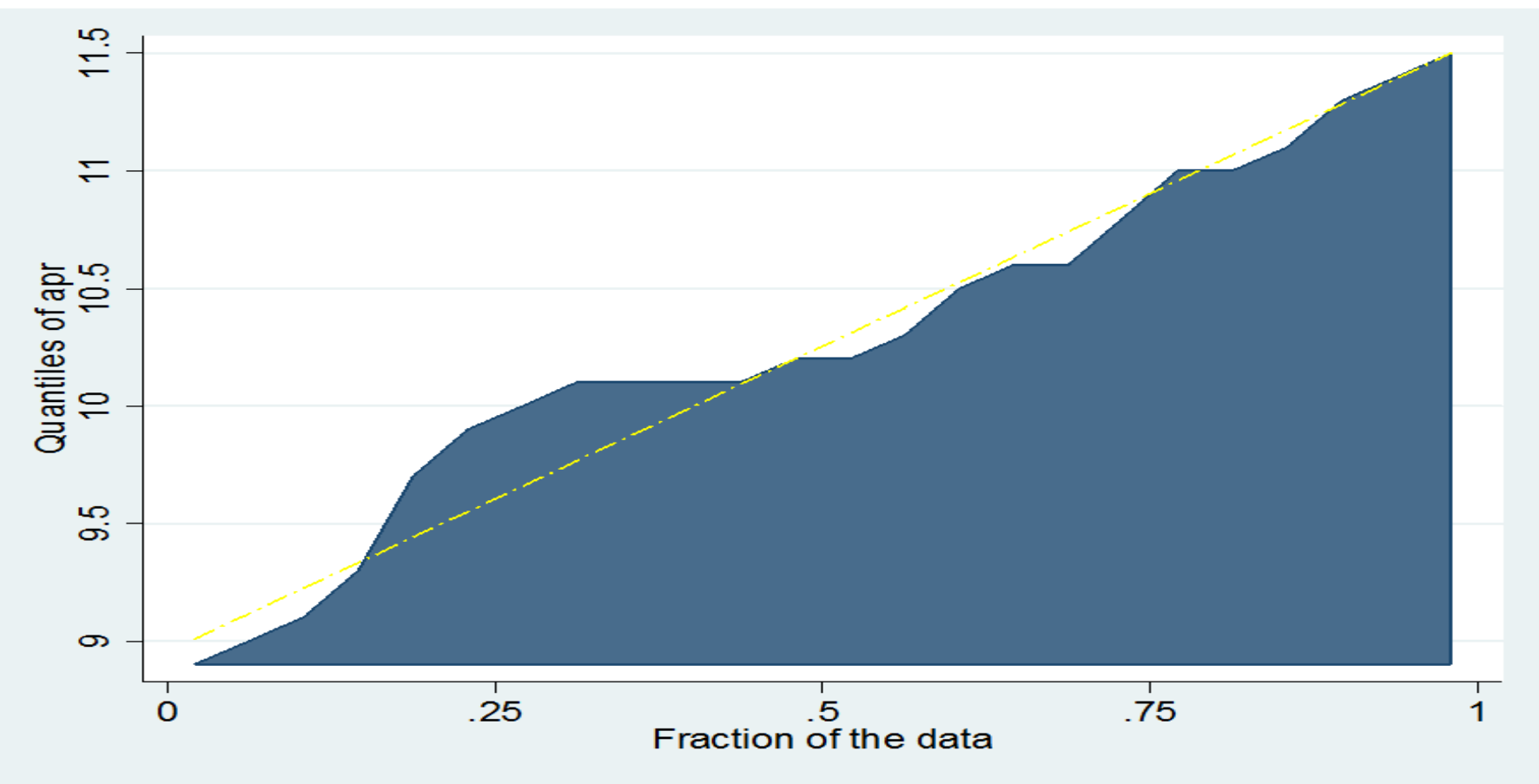

Source: Authors' Construct

Figure-1. Agribusiness growth showing at Different Quantiles [18].

In addition, the domestic consumption of edible beans in China increased to 4.4 million tons in 2011, which was equivalent to $3.27 \mathrm{kgper}$ capital as compared to 9.9kgper capital in Japan in 2011 [19]. The agricultural sector in mainland China, aside its continual food supply to the large populace, gives more than eight hundred million jobs to farmers dwelling in both rural and urban areas [20]. China's agricultural sector has experienced rapid growth in other sectors such us livestock, fishery and forestry aside the crop-first agriculture. After 1978 reforms, the output growth of crop reduced from $82 \%$ in 1970 to $55 \%$ in 2010 , whilst the fishery production also moved from $2 \%$ in 1979 to $10 \%$ in 2010 and forestry sector recorded $4 \%$ in 2010 [8]. For the past decade, there has been a rapid growth in the output of livestock and fishery production as compared to that of crop production due to dietary changes.

The effect of the various institutional reforms in promoting China's agriculture sector has been subjected to rigorous research [8, 12, 21-29]. In theory, the growth of agriculture sector is attributed to many factors, such as fertilizer application, the use of agricultural machinery, increase in agricultural and non-agricultural labor, and more importantly the introduction of household responsibility system, which was formally called production teams [30, 31 ].

The aim of this paper is to adopt flexible statistical techniques to investigate the effect of the various reforms on the growth of agribusiness in Mainland China. Surprisingly, few studies on this topic has employed semi-parametric regression model to study the complex relationship between rural policies and growth in agribusiness sector. However, we adopt quantile regression, which is the appropriate quantitative technique to measure the effect predictor variables on agricultural growth in rural China.

The rest of the study is organized as follows. Section 2 reviews the related literature. Section 3 presents the source of data. Section 4 describes methodology and model specification. Section 5 summarizes empirical results and discussion of findings. Section 6 provides concluding remarks.

\section{Related Literature}

After successful rural reforms in China, the change from the commune system to the household responsibility system (HRS) in the late 1970 s and 1980 has been a major contributor to agribusiness sector and agricultural productivity growth [17, 20, 25, 29]. According to Huang, et al. [32] the implementation of household responsibility system increased agricultural production by $8.2 \%$ as compared to $2.7 \%$ before the reform period. 
Moreover, the study conducted by Fan and Pardey [28] also revealed that between the period of 1965 to 1993 , the institutional reform policy contributed to the growth of agriculture by 17.6 percent.

EDU

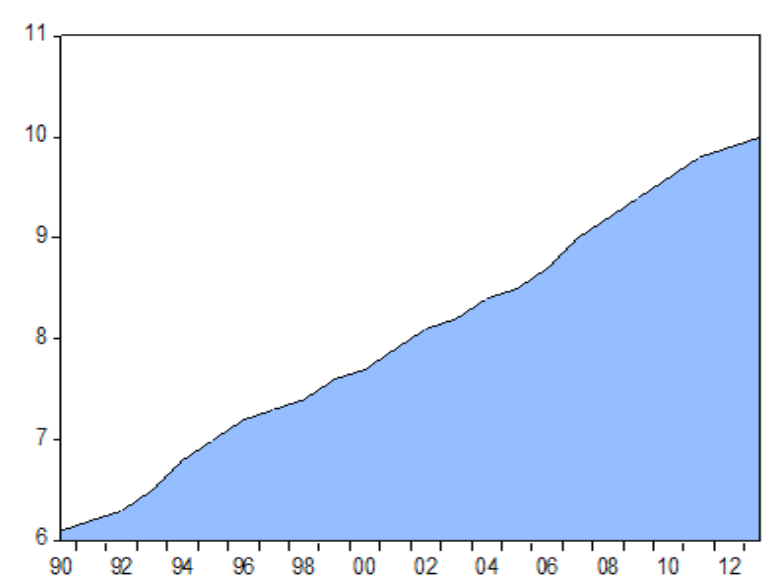

RD

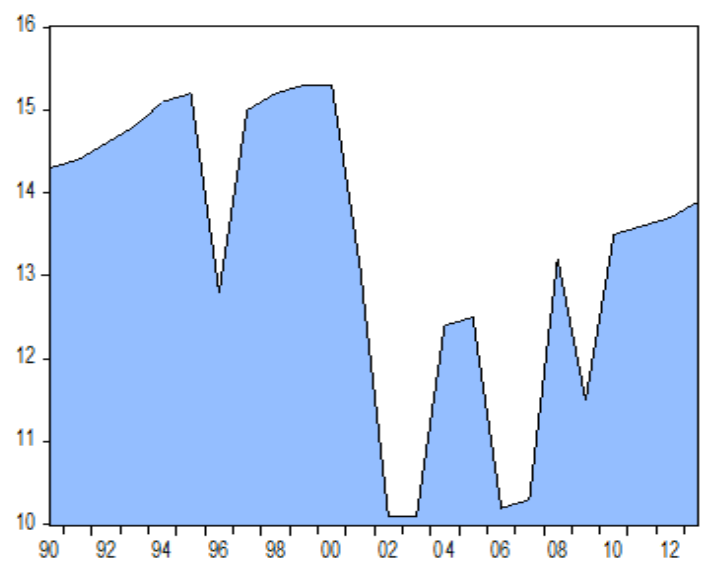

HLT

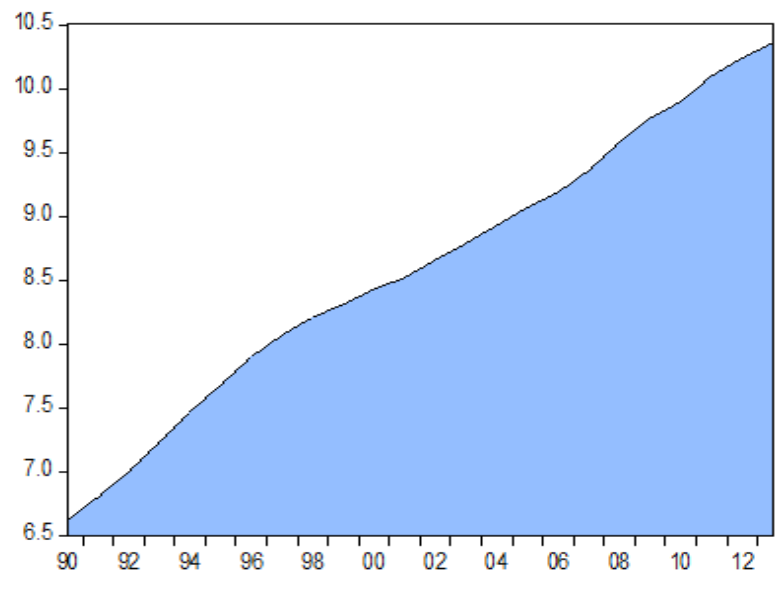

HSD

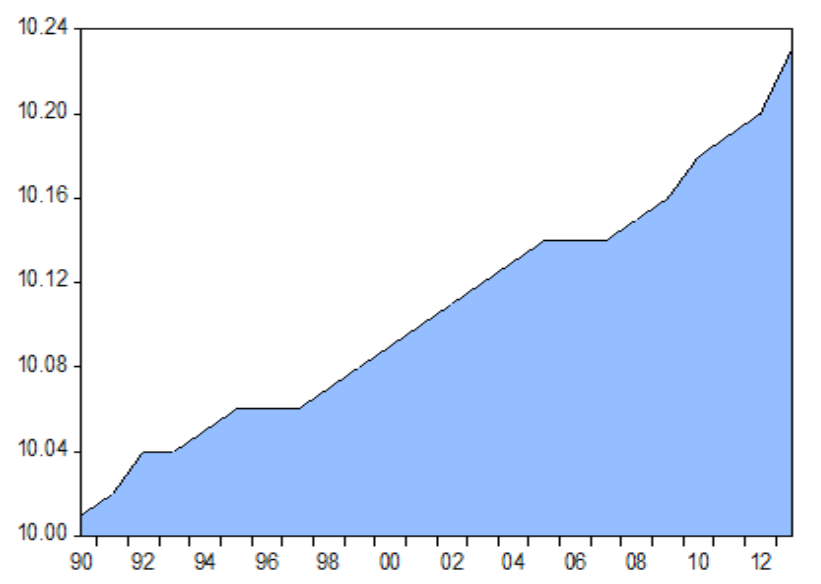

Figure-2. The trend of family household and public investments in health, education and agricultural research from 1990-2013 [18]. Source: Authors' Construct

Moreover, government investment in agricultural research and development has resulted in the introduction of new varieties of crops, which has increased food production in rural China [33]. In addition, the massive economic reforms and rapid economic growth in China has increased government investment in the health sector, which has resulted in the provision of quality health services in rural China [34, 35].

According to literature, the monetary investments in education, which consist of in-school and out-of-school expenditure, which serve as a major aspect of human capital investment has improved the standard of education among farmers resulting into an increase in agricultural production [36]. Most studies conducted in China's agricultural sector have ascribed the rapid growth of agriculture to several factors. For example, McMillan, et al. [37] investigated into the impact of China's economic reforms and agricultural productivity growth. They established that price adjustment policies have increased the productivity growth of agriculture. Wu, et al. [38] use a non-parametric Malmquist procedure to investigate the temporal and spatial nature of agricultural productivity growth over the study period (1988-1995). The authors concluded that agricultural productivity growth in mainland China has increased through continuing innovation, the use of modern inputs and competitive market. In this line of research Huang and $\mathrm{Ma}[15]$ analyzed the determinants of public and farm household capital stock formation and their effects on the productivity growth of agriculture. By using Cobb-Douglas production function, the study reveals that capital investment in agriculture, private capital formation and technological changes have increased agricultural growth while fertilization application has had mild agricultural growth. [12] using province-level panel data investigated the effect of rural reforms on agricultural growth in rural China. By employing Cobb-Douglas production function, the author indicated that decollectivation and adjustment in state procurement prices have augmented the growth of agricultural production. Lezin and Long-Bao [16] explored the impact of production variables used on agricultural productivity growth. However, using 1989-2002 data for Zhejiang Province and employing Cobb-Douglas production function, the study indicates that there is a strong correlation between the production variables and agricultural productivity growth. Xu [17] used of Cobb-Douglas production function to synthesis the empirical literature on the subject Chinese agricultural growth in post-reform Era. The study reveals that there is a relationship between household responsibility system and agricultural productivity growth. Li [39] adopted Stochastic Frontier Analysis and employed 1995-2009 village-level data to investigate the effect of China's Agricultural reforms on productivity changes. The study disclosed that for the past fifteen years, Chinese Agricultural productivity has increased due to the institution of agricultural policies (such as tax exemptions, insurance for farmers), and technological changes. Based on the related literature, an important aspect of measuring the productivity growth of agriculture, which is necessary but have been over-looked, is the estimation of the conditional median or the other quartiles of agricultural growth and not only the mere conditional mean.

\section{Data Source and Model Specification}

\subsection{Data Source}

The data set consist of a country-data for 23 years observation over the period 1990-2013, which is obtained from China Statistical Yearbook, various issues, 2015. The data on agribusiness development consists of a country- 
data from the period of 1990 to 2013 obtained from China Statistical Yearbook, various issues, 2015. Agribusiness performance (AGB) is measured by total profit of agro-industries in rural China within the study period. Family household refers to the total number of farmers in the various households from 1990 to 2013 in China. Expenditure in education includes government appropriations for education, which consists of rural expenditure on education, taxes, and fees, collected for education by the government, which is measured in 10000 Yuan. Agricultural Research $\&$ Development expenditure capture the public total expenditure on research and development in agricultural sector that is measured in 10000 Yuan. Government expenditure in health is the previous and current expenditure by the government in the health of rural people measured in 100 million Yuan. All the variables were converted into log form to avoid heteroskedasticitity, which will help us to estimate elasticity.

Table-1. Variables Definition

\begin{tabular}{l|l|l|l}
\hline Variable & Definitions & Unit & Source \\
\hline AGB & Agribusiness Growth & 100 million Yuan & China Statistical Yearbook \\
\hline HSD & $\begin{array}{l}\text { The total number of farmers in the various family } \\
\text { households }\end{array}$ & Household & China Statistical Yearbook \\
\hline EDU & Government investment in rural education & 10 ooo Yuan & China Statistical Yearbook \\
\hline HLT & Government expenditure in rural health & 100 million Yuan & China Statistical Yearbook \\
\hline R\&D & $\begin{array}{l}\text { Government expenditure in agricultural research and } \\
\text { development }\end{array}$ & 10 oo0 Yuan & China Statistical Yearbook \\
\hline Note: All the variables are annual data from 1990-2013.
\end{tabular}

Note: All the variables are annual data from 1990-2013.

Data source: National Bureau of Statistics of China China Statistical Yearbook [18]

\subsection{Model Estimation}

The quantile regression method proposed by Koenker and Bassett [40] performs regression analysis of sample data at different quantile points. Thus conditional quantile estimates are performed by quantile regression with each nth quantile showing different behavior in the conditional distribution [41]. The quantile regression generalized median regression estimate to other quantiles. However, the use of traditional regression (OLS) only pays attention to the mean effects, which may result in either over estimation or under estimation of coefficients and even fail to identify the actual relationships that exist between variables [42].

To investigate the role of institutional policies in promoting agribusiness development, the study adopts quantile regression $(\mathrm{QR})$ over the ordinary least square model (OLS) for the estimation. The Least squares regression only measures how the changes in the vectors of the covariates affects the conditional mean function of . Furthermore, OLS regression is very sensitive to outliers, which may lead to inaccurate predictions due to the presence of multicollinearity, abnormal distribution and the independent nature of the residuals [43]. Moreover, QR is invariant to monotonic transformation which is different from OLS [40,43]. In addition, QR is more robust to the non-normal error term and outliers in the model and takes into consideration the major effects of the covariates on the distribution of the dependent variable holistically and not only the conditional mean. However, this study employs the specifications of the previous literature on quantile regression.

As stated by Chen [44] the quantile regression generalizes the concept of a univariate quantile to a conditional given qauntile or many covariates and is modeled as follows;

For a random variable $\mathrm{Y}$ with probability distribution function

$$
F(y)=\operatorname{Pr} o b(Y \leq y)
$$

The $\tau$ th quartile of $\mathrm{Y}^{*}$ is defined as the inverse function

$$
Q(\tau)=\inf \{y: F(y) \geq \tau\},
$$

Where $0<\tau<1$. In particular, the median is $Q(1 / 2)$. According to Chen $[44]$ for random sample $\left\{y_{1}, \ldots, y_{n}\right\}$ of $\mathrm{Y}$, it is known that the sample median minimizes the sum of absolute deviations $\min _{\alpha \in R} \sum_{i=1}^{d}\left|y_{i}-\alpha\right|$.

As compare to the general $\tau$ th sample quantile $\alpha(\tau)$, which is analogue of $Q(\tau)$ is donated by

$\min _{\alpha \in R} \sum_{i=1}^{d} \rho_{\tau}\left(y_{i}-\alpha\right)$, where $\rho_{\tau}(z)=z(\tau-I(z<0)), 0<\tau<1$

Thus, I(.) is the indicator function. Chen [44] further argues that likewise the sample mean, which tries to minimize the sum of the squared residuals

$$
\hat{\sigma}=\arg \min _{\sigma \in} R \sum_{i=1}^{d}\left(y_{1}-\sigma\right)^{2}
$$

is extended to linear conditional mean function as $E(Y \mid X=x)=x^{\prime} \beta$ by solving

$$
\hat{\beta}=\arg \min _{\beta \in} R^{H} \sum_{i=1}^{d} \rho \tau\left(y_{i}-x_{i}^{\prime} \beta\right)^{2}
$$

the linear conditional quantile function modeled as $Q(\tau \mid X=x)=x^{\prime} \beta(\tau)$, is also estimated by solving

$$
\hat{\beta}(\tau)=\arg \min _{\beta \in} R^{H} \sum_{i=1}^{d} \rho \tau\left(y_{i}-x_{i}^{\prime} \beta\right)
$$

for any quantiles $\tau \in(0,1)$. The, quantity $\hat{\beta}(\tau)$ represents the $\tau$ th regression quantiles. 
The $\tau=0.5$, denotes the median regression called the $L_{1}$ regression, following Chen [44].

\subsection{Discussion of Results}

The study, however, measured the effect of the dependent variables on the response variable by adopting quantile regression model. For effective comparison, we present the OLS estimate, which serves as the baseline of mean effect and compare to the results of the selected quantiles in the conditional distribution of output produced in table 5 . The estimation of quantile regression is reported in table 5 at 15 th, 25 th, 35 th, 45 th, 55 th, 65 th, 75 th, 85 th, and $95^{\text {th }}$ quantiles.

Table 5 presents the estimation of a quantile regression model whereby family household and government investments in rural health, rural education and agricultural research and development are used to measure the agroindustry performance in China. From the results, the values of the parameters used for the estimation vary across OLS and the selected quantiles both in magnitude and direction. For example, Table 2 shows that the coefficient of family household in the 90th quantile is 24 times more than the OLS estimate results.

According to the coefficients of family household in Table 2, the contribution of farmers in each household to the growth of agribusiness sector in the lower quantiles is negative. However, the coefficients of OLS estimate to the lowest quantile (15th, 25 th, 35 th, 45 th, and 55 th quantile), are significant at the $10 \%$ level. Moreover, the influence of individual-based farming system in the various households on agro-industry growth increases at the higher quantile and significant at the lower quantile (Fig. 3). This implies that an increase in farmers in the family household corresponds with the agribusiness development in the higher quantile of the distribution. In our opinion, this due to the technological changes in the agricultural sector, whereby farmers use simple farm tools to boost food production. In addition, land fragmentations, which is a major problem facing smallholder farmer, and increase in off-farm employment among the youth and the able-bodied people in the rural areas are contributing factors contributing to the poor performance of family household to the agricultural growth in the lower quantiles and OLS estimate results. From Table 2, the OLS results indicate that a unit increase in family household reduces agricultural productivity growth by 2.62 percent.

Furthermore, the results of the study indicate some variations across selected percentiles in the conditional distribution of agribusiness growth. This shows the heterogeneity in the effect of rural health investments in agribusiness performance. The coefficient is significant and has a positive impact across the selected quantiles and OLS estimates at $1 \%$ and 10\% levels, whereby, the magnitude increases and then decreases toward the higher quantile (Fig. 3). The results imply that, all things being equal, improve health status among rural farmers in China contributes greatly to the development in the agribusiness sector at both the OLS estimate and the selected quantiles. This is due to increasing government spending in rural health, as a means of developing the human capital in the rural areas to increase food production. According to Sckokai and Moro [45] effective government policies promote agribusiness sector and agricultural growth and more importantly, create agricultural and non-agricultural jobs that increase farmers' income level. Report from Chappell and LaValle [3] indicates that life expectancy increased from $67.77 \%$ in 1981 to $74.83 \%$ in 2010 and, there was a dropped in Infant Mortality Rate (IMR) from $32.89 \%$ in 1990 to $13.93 \%$ in 2012.

Table-2. Institutional policies and agribusiness development: OLS versus quantile regressions. (Dependent variable is total profit of agro-industries from 1990 to 2013 )

\begin{tabular}{|c|c|c|c|c|c|c|c|c|c|c|}
\hline \multirow[t]{2}{*}{ Coefficients } & \multirow[b]{2}{*}{ OLS } & \multirow[b]{2}{*}{$\underset{(.15)}{\mathrm{Q}}$} & \multirow[b]{2}{*}{$\underset{(.25)}{\mathrm{Q}}$} & \multicolumn{2}{|c|}{ Selected Quantiles } & \multirow[b]{2}{*}{$\underset{(.55)}{\mathrm{Q}}$} & \multirow[b]{2}{*}{$\underset{(.65)}{Q}$} & \multirow[b]{2}{*}{$\underset{(.75)}{\mathrm{Q}}$} & \multirow[b]{2}{*}{$\underset{(.85)}{Q}$} & \multirow[b]{2}{*}{$\underset{(.95)}{Q}$} \\
\hline & & & & $\begin{array}{c}\mathrm{Q} \\
(.35)\end{array}$ & $\begin{array}{c}\mathrm{Q} \\
(.45)\end{array}$ & & & & & \\
\hline \multirow[t]{2}{*}{ constant } & $29.29^{*}$ & 22.93 & $26.35^{*}$ & $36.42^{*}$ & 45.28 & 48.78 & 5.65 & 13.22 & 7.93 & 5.65 \\
\hline & $(1.48)$ & $(0.82)$ & $(0.87)$ & $(1.09)$ & $(1.38)$ & $(1.71)$ & $(0.11)$ & $(0.34)$ & $(0.17)$ & $(0.11)$ \\
\hline \multirow[t]{2}{*}{$H S D$} & -2.62 & $-1.92^{*}$ & $-2.31^{*}$ & $-3.35^{*}$ & $-4.28^{*}$ & $4.63^{*}$ & 0.11 & 0.93 & 0.35 & 0.11 \\
\hline & $(1.29)$ & $(0.67)$ & $(0.67)$ & $(0.97)$ & $(1.26)$ & $(1.55)$ & $(0.02)$ & $(0.23)$ & $(0.07)$ & $(0.02)$ \\
\hline \multirow[t]{2}{*}{$H L T$} & $0.89 * * *$ & $0.59^{* * *}$ & $0.71 * * *$ & $0.76^{* *}$ & $0.88^{* *}$ & $0.83^{* *}$ & $0.87^{*}$ & $0.65^{*}$ & $0.75^{*}$ & $0.88^{*}$ \\
\hline & $(4.32)$ & $(1.92)$ & $(1.96)$ & $(2.03)$ & $(2.01)$ & 1.72 & $(1.12)$ & $(1.16)$ & $(1.01)$ & $(1.12)$ \\
\hline \multirow[t]{2}{*}{$E D U$} & -0.07 & 0.17 & 0.11 & 0.1 & 0.42 & 0.94 & 0.24 & 0.36 & $0.08 * *$ & $0.24 * *$ \\
\hline & $(0.33)$ & $(0.58)$ & $(0.33)$ & $(0.310$ & $(0.12)$ & $(0.25)$ & $(0.43)$ & $(0.08)$ & $(0.16)$ & $(0.43)$ \\
\hline \multirow[t]{2}{*}{$R \Theta^{2} D$} & $0.03^{*}$ & $0.01^{*}$ & 0.03 & $0.02 * *$ & 0.26 & 0.02 & $0.02^{*}$ & $0.04 * *$ & $0.02 *$ & $0.02 *$ \\
\hline & $(1.48)$ & $(1.15)$ & $(2.56)$ & $(1.94)$ & $(2.43)$ & $(1.99)$ & (0.68) & $(1.79)$ & (0.88) & (0.68) \\
\hline Observation & 23 & 23 & 23 & 23 & 23 & 23 & 23 & 23 & 23 & 23 \\
\hline $\mathrm{R}$-square & 0.9843 & & & & & & & & & \\
\hline Pseudo & & 0.9295 & 0.9157 & 0.9055 & 0.899 & 0.8943 & 0.889 & 0.8823 & 0.8789 & 0.8903 \\
\hline
\end{tabular}

Note: $t$ statistics are in parentheses.

* $P<0.10,{ }^{* *} P<0.05$, **** $P<0.01$

The per-capita health spending of urban area as compared to rural health investment was less than $2 \%$ in early 1990 s, but increased to $2.67 \%$ in 2010 . The $2.67 \%$ increased in health expenditure recorded in 2010 is attributed to the implementation of the new Rural Cooperate Medical Scheme (NRCMS) and the current reforms [46-48]. This led to rapid increase in agro-industry performance in the agribusiness distribution.

In addition to these, the contribution of rural investment in education to agro-industry performance is statistically insignificant across the selected quantiles but recorded positively at the OLS estimate. Table 2 clearly shows that the coefficients of the number of variables used differ across OLS and the quantile levels. As demonstrated in Figure 3, the impact of investment in rural education in agribusiness development across different quantiles is positive and its influence under 55th quantile is higher than the estimates above 90th quantile. The results of the OLS estimate suggest that a percentage increase in rural investment in education decreases agribusiness performance by 0.07 percent. This supports why the study adopted quantile regression model to measure the effect at the various quintile points other than using only OLS model. However, the contribution of public investment in education to the agro-industries performance across the selected quantiles recorded positively. For instance, from Table 2 the output 
growth at 55th quantile is greater than those in 15 th, 25th, 35th, 45th, 65th, 75th, 8th, and 95th quantiles. From Figure 3, results for both family household and rural education give clear indications of the changes in the coefficients throughout the distribution of agribusiness development. The quantile regression shows significantly negative effect of household at 15th to 45th quantiles, however, the impact is positive at the upper quantiles of the conditional distribution. Although, the results of family household contradicts the results of various studies, we will not make any policy conclusion from the results, but has to be thorough investigated.
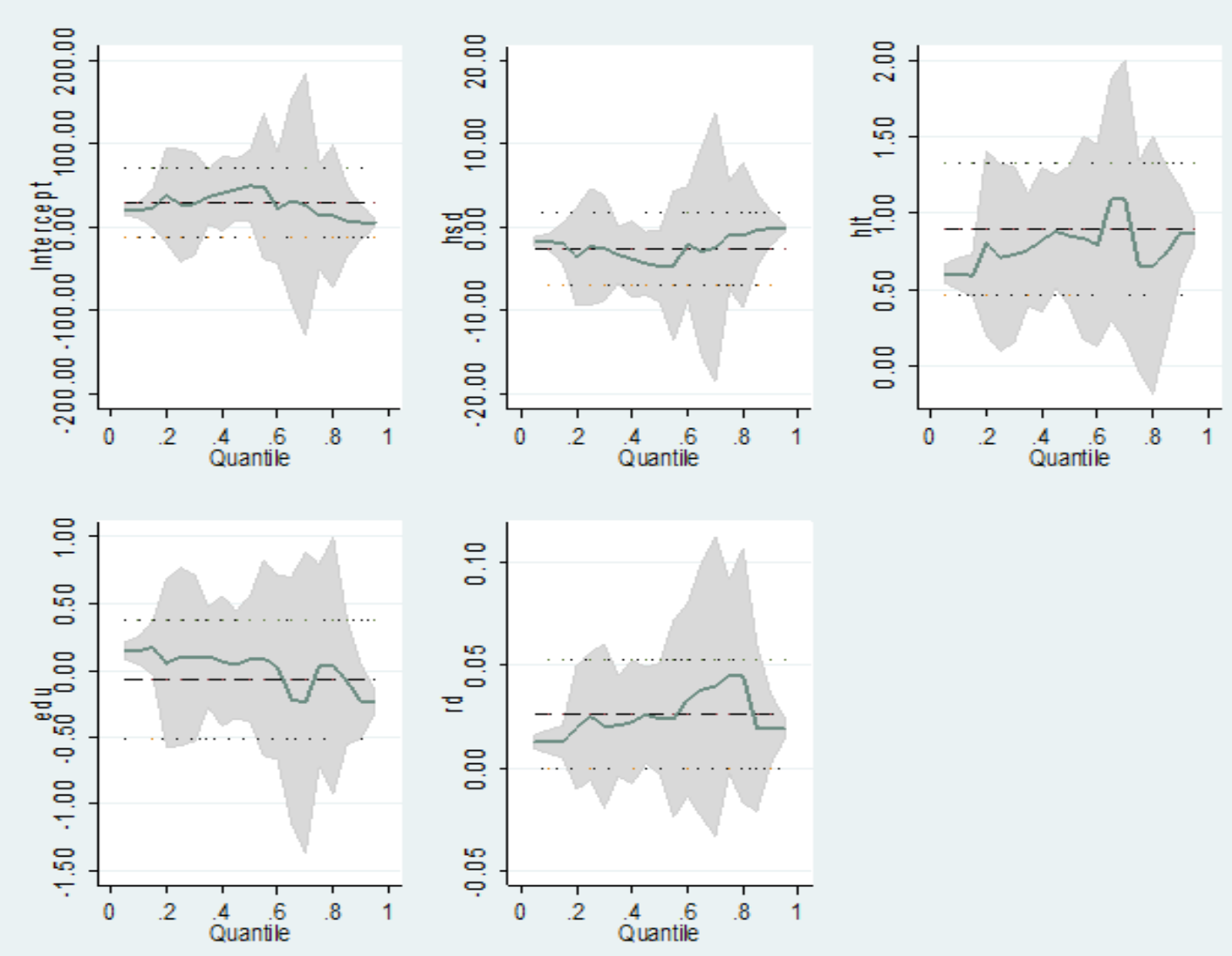

Figure-3. The effects of family household (hsd), rural investment in education (edu), health (hlt) and agricultural R\&D (rd) agribusiness development (ABD): OLS versus quantile regression.

Notes: The dashed lines represent OLS parameter estimate, and the dark shaded areas are confidence intervals for the estimation of quantile regression parameters.

Data source: National Bureau of Statistics of China China Statistical Yearbook [18]

In our view, the growth in the various quantiles from Table 2 is due to improvement in the educational system in rural areas, which has gone a long way to improve the skills of agricultural entrepreneures in rural China.

Finally, for agricultural $\mathrm{R} \& \mathrm{D}$, the results indicate that the impact of research and development on agribusiness performance is positively significant across the quantiles at $1 \%, 5 \%$ and $10 \%$ level. However, the effect on agribusiness development differs slightly, despite its positive effect on at all selected quantiles. For instance, the coefficient of R\&D at 25th quantile is the same as compare to the coefficient in OLS regression. According to OLS results, an increase in entrepreneurial knowledge increases agribusiness growth by $0.03 \%$ within the study period. Moreover, the parameter estimate of the OLS regression is quite lower than the estimate results in the 45th quantile but higher than the values for 15 th, 35 th, 55 th, 65 th, 85 th, and 95 th quantiles. This confirms study conducted by Audretsch, et al. [49] which maintained that investment in new knowledge promotes productivity growth. The contribution of $\mathrm{R} \& \mathrm{D}$ to agribusiness development may attribute to high investment in research and development. According to Liu, et al. [50] patent applications and grants in the agricultural sector has increased over the past decades, which has promoted agricultural production.

\section{Conclusion}

Using time series data in PR China from 1990-2013, this paper measures the linkage between institutional policies and agribusiness development in China. That is the impact of government investment in education, health research and development and the introduction family households on agribusiness sector. The study however, adopted OLS mean regression and compared with quantile regression because OLS regression model only expresses the conditional mean in a linear form. The results indicate that the impact of rural investments on agribusiness development in China is quite heterogeneous. For instance, effects family household on growth of agribusiness sector across the selected quantiles are negative but significant at 15 th, 25th, 35th, 45th, and 55th quantiles. However, agribusiness development continuously increases at 85th and 95th quantiles. The influence of rural investment in health on the agribusiness sector increases monotonically across the quantile distribution. For instance, the output growth in 15 th and 75 th quantiles are lower than 25 th, 35th, and 85th quantiles but at the 45th, 55th, and 95th quantiles, health influence on agro-industry performance is stronger. This is due to the desire of the government to ensure the well-being of the people and promote human capital development through provision of effective health care system. Moreover, the contribution of educational investment to agribusiness development at 55 th quantile of the distribution is greater than the effect at the higher quantiles of the distribution. The difference in the output growth at different quantiles may be attributed to the inability of smallholder farmers to identify the various opportunities in the farming business and have access to the technological market. The reason is that most farmers in the rural areas still use traditional farm tools for farming activities and engage in subsistence farming. Based on 
the results from the quantile regression, we suggest that policy makers could be misled by using simple results achieved by OLS regression to determine the effect of institutional policies on agribusiness development. This is because simple aggregations achieved by simple regression fail to indicate the existence of predictability in the exogenous variables.

\section{References}

[1] J. Hansen, F. Tuan, and A. Somwaru, "Do China's agricultural policies matter for world commodity markets?," China Agricultural Economic Review, vol. 3, pp. 6-25, 2011. View at Google Scholar | View at Publisher

[2] G. McElwee, "Developing entrepreneurial skills of farmers. A Literature Review of Entrepreneurship in Agriculture." Retrieved from http://www.esofarmers.org/documents/ESoFliteraturereview_000.pdf, 2005.

[3] M. J. Chappell and L. A. LaValle, "Food security and biodiversity: Can we have both? An agroecological analysis," Agriculture and Human Values, vol. 28, pp. 3-26, 2011 . View at Google Scholar |View at Publisher X. Diao, P. Hazell, and J. Thurlow, "The role of agriculture in African development," World Development, vol. 38, pp. 1375-1383, 2010. View at Google Scholar | View at Publisher

[5] J. M. Dieterle, "Just food: Philosophy," Justice and Food, 2015

[6] X. Zhu, "Understanding China's growth: Past, present, and future," Journal of Economic Perspectives, vol. 26, pp. 103-124, 2012. View at Google Scholar | View at Publisher

J. C. Aker, "Dial "A" for agriculture: A review of information and communication technologies for agricultural extension in developing countries," Agricultural Economics, vol. 42, pp. 631-647, 2011. View at Google Scholar | View at Publisher

[8] J. Huang and S. Rozelle, The role of agriculture in China's development: Performance, determinants of successes and future challenges emerging economies: Springer, 2015.

[9] B. F. Johnston, "Agriculture and structural transformation in developing countries: A survey of research," Journal of Economic Literature, vol. 8, pp. 369-404, 1970. View at Google Scholar

[10] D. Kleine, "Who will feed China?," Journal of Soil and Water Conservation, vol. 52, pp. 398-399, 1997. View at Google Scholar

[11] W. M. Liefert and P. C. Westcott, "Modifying agricultural export taxes to make them less market-distorting," Food Policy, vol. 62, pp. 65-77, 2016. View at Google Scholar | View at Publisher

[12] J. Y. Lin, "Rural reforms and agricultural growth in China," American Economic Review, pp. 34-5 1, 1992. View at Google Scholar

[13] X. Xin and F. Qin, "Decomposition of agricultural labor productivity growth and its regional disparity in China," China Agricultural Economic Review, vol. 3, pp. 92-100, 2011 . View at Google Scholar | View at Publisher

[14] A. Pufahl and C. R. Weiss, "Evaluating the effects of farm programmes: Results from propensity score matching," European Review of Agricultural Economics, vol. 36, pp. 79-101, 2009. View at Google Scholar | View at Publisher

[15] J. Huang and H. Ma, Capital formation and agriculture development in China: Rome: FAO, 2010.

[16] W. A. B. H. Lezin and W. Long-Bao, "Agricultural productivity growth and technology progress in developing country agriculture: Case study in China," Journal of Zhejiang University-Science A, vol. 6, pp. 172-176, 2005. View at Publisher

[17] M. Xu, "Chinese agricultural growth in post-reform Era," Advances in Computer Science and Engineering, pp. 71 1-715, 2012. View at Google Scholar $\mid$ View at Publisher
National Bureau of Statistics of China China Statistical Yearbook, Retrieved from National Bureau of Statistics of China China Statistical Yearbook,
http://www.stats.gov.cn/enGliSH/Statisticaldata/AnnualData/.

[19] Y. F. Chen, Z. G. Wu, T. H. Zhu, Y. Lei, and H. P. Chien, "Agricultural policy, climate factors and grain output: Evidence from household survey data in rural China," Journal of Integrative Agriculture, vol. 12, pp. 169-183, 2013. View at Google Scholar | View at Publisher

[20] L. Yunhua and W. Xiaobing, "Technological progress and Chinese agricultural growth in the 1990s," China Economic Review, vol. 16, pp. 419-440, 2005. View at Google Scholar | View at Publisher

[21] D. G. Johnson, "China's rural and agricultural reforms in perspective: Publisher not identified," 1998.

[22] Z. Ling, "Rural reform and peasant income in China," Impact of China's Post Mao Rural, 1991.

[23] A. Nin-Pratt, B. Yu, and S. Fan, "Comparisons of agricultural productivity growth in China and India," Journal of Productivity Analysis, vol. 33, pp. 209-223, 2010. View at Google Scholar |View at Publisher

[24] C. Po-Chi, Y. Ming-Miin, C. C. Chang, and H. Shih-Hsun, "Total factor productivity growth in China's agricultural sector," China Economic Review, vol. 19, pp. 580-593, 2008. View at Google Scholar | View at Publisher

[25] L. J. Zhang, Y. Tang, and B. H. Liu, "Changes in agricultural system as farmers adapt to economic-social and climatic changes in the min upriver rural areas in Western Sichuan, South Western China," Journal of Mountain Science, vol. 12, pp. 747-758, 2015. View at Google Scholar | View at Publisher

[26] L. Zhou and H. P. Zhang, "Productivity growth in China's agriculture during 1985-2010," Journal of Integrative Agriculture, vol. 12, pp. 1896-1904, 2013. View at Google Scholar | View at Publisher

[27] L. Zhu, Rural reform and peasant income in China. London: Blacnillan, 1991.

[28] S. Fan and P. G. Pardey, "Research, productivity, and output growth in Chinese agriculture," Journal of Development Economics, vol. 53, pp. 115-137, 1997. View at Google Scholar | View at Publisher

[29] S. Fan, L. Zhang, and X. Zhang, "Reforms, investment, and poverty in rural China," Economic Development and Cultural Change, vol. 52, pp. 395-42 1, 2004. View at Google Scholar | View at Publisher

[30] C. Ding, "Policy and praxis of land acquisition in China," Land Use Policy, vol. 24, pp. 1-13, 2007. View at Google Scholar | View at Publisher

[31] D. Goodman, "Organic and conventional agriculture: Materializing discourse and agro-ecological managerialism," Agriculture and Human Values, vol. 17, pp. 215-219, 2000. View at Google Scholar

[32] J. Huang, K. Otsuka, and S. Rozelle, "Agriculture in China's development: Past disappointments, recent successes, and future challenges," China's Great Economic Transformation, pp. 467-505, 2008. View at Google Scholar | View at Publisher

[33] S. Fan, C. Fang, and X. Zhang, "Agricultural research and urban poverty: The case of China," World Development, vol. 31, pp. 733-741, 2003. View at Google Scholar | View at Publisher

[34] K. Fuglie and D. Schimmelpfennig, "Introduction to the special issue on agricultural productivity growth: A closer look at large, developing countries," Journal of Productivity Analysis, vol. 33, pp. 169-172, 2010. View at Google Scholar | View at Publisher

[35] S. Tang, Q. Meng, L. Chen, H. Bekedam, T. Evans, and M. Whitehead, "Tackling the challenges to health equity in China," Lancet, vol. 372, pp. 1493-150 1, 2008. View at Google Scholar | View at Publisher

[36] W. Chi and X. Qian, "Human capital investment in children: An empirical study of household child education expenditure in China, 2007 and 2011," China Economic Review, vol. 37, pp. 52-65, 2016. View at Google Scholar | View at Publisher

[37] J. McMillan, J. Whalley, and L. Zhu, "The impact of China's economic reforms on agricultural productivity growth," Journal of Political Economy, vol. 97, pp. 781-807, 1989. View at Google Scholar | View at Publisher

[38] S. Wu, D. Walker, S. Devadoss, and Y. C. Lu, "Productivity growth and its components in Chinese agriculture after reforms," Review of Development Economics, vol. 5, pp. 375-391, 2001. View at Google Scholar View at Publisher

[39] Z. Li. The change of Chinese agricultural productivity technology for education and learning. Springer. pp: 43-50, 2012.

[40] R. Koenker and J. G. Bassett, "Regression quantiles," Econometrica: Journal of the Econometric Society, pp. 33-50, 1978. View at Google Scholar

[41] B. Xu and B. Lin, "A quantile regression analysis of China's provincial CO 2 emissions: Where does the difference lie?," Energy Policy, vol. 98, pp. 328-342, 2016. View at Google Scholar | View at Publisher

[42] H. Zhu, L. Duan, Y. Guo, and K. Yu, "The effects of FDI, economic growth and energy consumption on carbon emissions in ASEAN5: Evidence from panel quantile regression," Economic Modelling, vol. 58, pp. 237-248, 2016. View at Google Scholar | View at Publisher

[43] H. Uematsu, A. R. Khanal, and A. K. Mishra, "The impact of natural amenity on farmland values: A quantile regression approach," Land Use Policy, vol. 33, pp. 151-160, 2013. View at Google Scholar | View at Publisher

[44] C. Chen, "An introduction to quantile regression and the QUANTREG procedure," presented at the Proceedings of the Thirtieth Annual SAS Users Group International Conference, 2005. 
[45] P. Sckokai and D. Moro, "Modelling the impact of the CAP single farm payment on farm investment and output," European Review of Agricultural Economics, vol. 36, pp. 395-423, 2009. View at Google Scholar | View at Publisher

[46] S. Hu, S. Tang, Y. Liu, Y. Zhao, M. L. Escobar, and D. De Ferranti, "Reform of how health care is paid for in China: Challenges and opportunities," Lancet, vol. 372, pp. 1846-1853, 2008. View at Google Scholar | View at Publisher

[47] W. Yip and W. Hsiao, "China's health care reform: A tentative assessment," China Economic Reviere, vol. 20, pp. 613-619, 2009. View at Google Scholar $\mid$ View at Publisher

[48] L. Zhu, "A review of rural healthcare system weaknesses in China: Moving toward universal coverage by applying the benchmarks of fairness," 2013. [49] D. B. Audretsch, A. Coad, and A. Segarra, "Firm growth and innovation," Small Business Economics, vol. 43, pp. 743-749, 2014. View at

[50] L. J. Liu, C. Cao, and M. Song, "China's agricultural patents: How has their value changed amid recent patent boom?," Technological Forecasting and Social Change, vol. 88, pp. 106-121, 2014. View at Google Scholar $\mid$ View at Publisher 